\title{
Formulasi Susu Pengganti dan Evaluasi Pengaruhnya terhadap Performa Anak Domba Kembar
}

\author{
Formulation of Milk Replacer and Evaluation of Its Effect on the Performance of Twin Lambs
}

\section{Asep Sudarman*, Fatmiati Harun dan Lilis Khotijah}

\author{
Department of Animal Nutrition and Feed Technology, Faculty of Animal Science, IPB University \\ Jl. Agatis Kampus IPB Darmaga, Bogor 16680. \\ *Corresponding e-mail: a_sudarman@yahoo.com
}

\begin{abstract}
The purpose of this experiment was to formulate and evaluate milk replacer on the production performance of twin lambs from before weaning to one month after weaning. Three pairs of twin lambs aged two weeks with a body weight of $3.83 \pm 0.4 \mathrm{~kg}$ were divided into two groups, each consisting of three lambs. The treatments applied were PSI $=$ lamb given mother's milk and PMR = lamb given milk replacer. Pre-weaning dry matter consumption data were analyzed descriptively and other data were analyzed using the T-test. The results showed that the dry matter consumption lambs that were given milk replacers in pre-weaning was $164.18 \pm 31.25$ $\mathrm{g} / \mathrm{head} / \mathrm{day}$ with the largest proportion coming from milk replacers (61.4\%). PSI group lambs had dry matter and energy consumption after weaning, daily gain before and after weaning, and body weight when weaned were significantly higher $(\mathrm{P}<0.05)$ than the PMR group lambs. However, the ratio of feed conversion and body weight at 90 days in the two groups of lamb were not significantly different. All lambs were healthy and no one died. It is concluded that formulated milk replacer provides production performance in lambs that are equivalent to lambs fed with mother's milk.
\end{abstract}

Key words: milk replacer, mother milk, performance, twin lambs

\begin{abstract}
ABSTRAK
Tujuan dari percobaan ini adalah untuk memformulasi dan mengevaluasi susu pengganti (milk replacer) terhadap kinerja produksi anak domba kembar dari sebelum disapih hingga satu bulan setelah disapih. Tiga pasang anak domba kembar berumur dua minggu dengan bobot badan 3,83 $\pm 0,4 \mathrm{~kg}$ dibagi menjadi dua kelompok yang masing-masing terdiri dari tiga ternak. Perlakuan yang diterapkan adalah PSI = anak domba yang diberi susu induk dan PMR = anak domba yang diberi milk replacer. . Data konsumsi pakan pra sapih dianalisis secara deskriptif dan data yang lain dianalisis dengan menggunakan uji-T. Hasil penelitian menunjukkan bahwa konsumsi BK anak domba yang diberi milk replacer pada pra sapih adalah sebesar 164,18 $\pm 31,25 \mathrm{~g} / \mathrm{ekor} / \mathrm{hari}$ dengan proporsi terbesar berasal dari milk replacer $(61,4 \%)$. Anak domba kelompok PSI memiliki konsumsi bahan kering dan energi setelah disapih, pertambahan bobot badan harian sebelum dan setelah disapih, dan bobot badan saat disapih nyata lebih tinggi $(\mathrm{P}<0,05)$ daripada anak domba kelompok PMR. Namun, rasio konversi pakan dan bobot badan umur 90 hari kedua kelompok anak domba tidak berbeda nyata. Semua anak domba sehat dan tidak ada kematian. Disimpulkan bahwa susu pengganti yang diformulasi memberikan kinerja produksi pada anak domba yang setara dengan anak domba yang diberi air susu induk.
\end{abstract}

Kata kunci: susu pengganti, susu induk, kinerja produksi, anak domba kembar

\section{PENDAHULUAN}

Beberapa domba di daerah tropis memiliki sifat unggul prolifik (beranak dapat lebih dari satu sekelahiran). Domba dengan sifat prolifik dapat memberikan keuntungan yang lebih besar kepada petenak domba apabila dapat dimanfaatkan dengan baik. Domba Garut diketahui memiliki sifat prolifik yang lebih tinggi dibandingkan domba ekor tipis. Pada kondisi lingkungan yang sama domba Garut mempunyai jumlah anak sekelahiran 1,86 sedangkan pada domba ekor tipis lokal 1,58 ekor/induk/tahun (Sugiyono, 2011). Keunggulan sifat prolifik tidak akan diperoleh bila tatalaksana produksi kurang baik yang dicirikan oleh tingginya mortalitas anak domba sebelum disapih, kecilnya bobot lahir dan bobot sapih anak domba kembar karena kekurangan asupan nutrien. Laporan Adiati dan Subandriyo (2007) memperlihatkan bahwa kematian anak domba sekelahiran kembar dua dan lebih dari dua pada umur $0-3$ hari 
adalah berturut-turut $30 \%$ dan $89 \%$, sedangkan kelahiran satu hanya 10\%. Hal demikian menyebabkan kelahiran anak domba kembar terkadang kurang diharapkan oleh peternak. Permasalahan tersebut disebabkan oleh produksi susu induk yang kurang untuk mencukupi kebutuhan anak yang banyak dalam satu kali kelahiran.

Produksi susu pada domba Garut terdapat perbedaan antara induk dengan anak tunggal dan anak kembar dua yaitu berturutturut 35,6 dan 39,9 kg/ekor/laktasi (Tiesnamurti et al., 2002). Hasil penelitian lain (Tiesnamurti, 1992) menunjukkan bahwa induk dengan anak tunggal, kembar dua dan kembar tiga mempunyai kemampuan sapih 90, 70 dan $60 \%$ dengan pemberian pakan yang baik. Kemampuan sapih induk dengan kelahiran kembar tiga akan menurun hingga $40 \%$ dengan memburuknya pakan yang diterima induk.

Penggunaan milk replacer atau pengganti air susu induk nampaknya merupakan salah satu cara yang dapat ditempuh dalam mengatasi permasalan tersebut. Penggunaan milk replacer pada domba telah berkembang di negara yang industri peternakannya sudah maju. Milk replacer diharapkan mampu membantu dalam menyediakan nutrien bagi anak domba pra sapih terutama anak domba kembar. Selain itu, dengan pemberian milk replacer diharapkan anak domba dapat disapih lebih awal sehingga induk dapat dikawinkan kembali dalam waktu yang lebih cepat. Namun penggunaan milk replacer belum umum digunakan oleh peternak di Indonesia, disebabkan harga milk replacer komersial yang sampai sekarang masih diimpor dan harganya masih dirasa mahal. Untuk itu perlu tersedia alternatif milk replacer yang terbuat dari bahan yang mudah diperoleh dan harganya tidak mahal. Penelitian ini bertujuan untuk menformulasi sendiri milk replacer dan mengevaluasinya dengan melihat pengaruh pemberian milk replacer buatan tersebut terhadap performa anak domba kembar dua dari umur dua minggu sampai lepas sapih.

\section{MATERI DAN METODE}

Penelitian ini dilaksanakan di Laboratorium Lapang dan Laboratorium Ilmu Nutrisi Ternak Daging dan Kerja, Departemen Ilmu Nutrisi dan Teknologi Pakan, Fakultas Peternakan, Institut Pertanian Bogor.

\section{Ternak dan Pakan}

Ternak yang digunakan dalam penelitian ini adalah tiga pasang anak domba kembar dua hasil persilangan domba lokal ekor tipis dan domba Garut yang berasal dari tiga induk dan waktu kelahiran yang berbeda. Ternak tersebut dikandangkan secara individu, dimana anak yang diberi susu pengganti/milk replacer (PMR) dipisah dari induknya, sedangkan anak yang memperoleh air susu induk (PSI) dikandangkan bersama induknya.

Pakan yang digunakan selama penelitian berupa rumput lapang dan konsentrat komersil. Kandungan nutrien rumput lapang dan konsentrat komersil dicantumkan pada Tabel 1 .

Tabel 1. Kandungan nutrien hijauan dan konsentrat yang digunakan beradasarkan persentase berat kering

\begin{tabular}{lcc}
\hline Zat Makanan & Hijauan & Konsentrat \\
& & \\
\hline Bahan Kering (\%) & 23,31 & 86,76 \\
Protein Kasar (\%) & 8,7 & 19,2 \\
Abu (\%) & 6,46 & 9,19 \\
Lemak Kasar (\%) & 1,50 & 7,49 \\
Serat Kasar (\%) & 27,78 & 17,87 \\
GE (kal/g) & 4.294 & 4.693 \\
\hline
\end{tabular}

Hasil Analisa Laboratorium Ilmu dan Teknologi Pakan, IPB (2012)

Milk replacer yang digunakan selama penelitian diformulasi dan dicampur dari susu sapi murni, kuning telur, minyak ikan dan premix. Kandungan nutrien milk replacer dan susu domba disajikan pada Tabel 2. 
Tabel 2. Kandungan nutrien milk replacer dan susu domba

\begin{tabular}{lcc}
\hline Zat Makanan & Milk replacer & Susu Domba* \\
\hline Bahan kering (BK), \% & 15,31 & 16,9 \\
Protein kasar (PK), \% & 26,27 & 27,8 \\
Lemak kasar (LK), \% & 31,76 & 33,13 \\
\multicolumn{2}{l}{ Hasil analisis Laboratorium Ilmu Hayati, Pusat Penelitian Sumberdaya Hayati dan Bioteknologi, IPB (2012) } \\
*Susu domba yang berasal dari induk yang digunakan pada saat penelitian
\end{tabular}

\section{Pemeliharaan}

Sebelum digunakan anak domba ditimbang bobot badannya terlebih dahulu. Penimbangan anak domba selanjutnya dilakukan setiap satu minggu sekali untuk mengetahui pertambahan bobot badannya. Milk replacer diberikan sebanyak tiga kali sehari dan sebelum diberikan ke anak domba dihangatkan terlebih dahulu sampai 35 $40^{\circ} \mathrm{C}$. Milk replacer yang diberikan sebanyak 3\% dari bobot badan berdasarkan bahan kering per hari. Pemberian pakan tambahan (hijauan dan konsentrat) diberikan sebanyak 2\% dari bobot badan berdasarkan bahan kering untuk anak yang dipisah dari induknya. Pemberian pakan (hijauan dan konsentrat) induk diberikan sebanyak 5\% dari bobot badan berdasarkan bahan kering.

Penyapihan dilakukan saat anak domba berumur 60 hari. Anak domba yang diberi susu induk (PSI) dipisahkan dari induknya dengan memindahkan ke kandang individu, sedangkan anak domba yang diberi milk replacer (PMR) tidak diberikan milk replacer lagi. Anak domba tersebut mulai hanya diberi hijauan dan konsentrat dan dipelihara sampai umur 90 hari. Setelah lepas sapih seluruh anak domba diberikan konsentrat dan hijauan dengan perbandingan 50:50 sebanyak 3\% dari bobot badan berdasarkan bahan kering. Pakan diberikan pagi, siang, dan sore hari dengan proporsi yang sama. Pemberian konsentrat diberikan terlebih dahulu dan setelah habis disusul segera dengan rumput. Sisa pakan ditimbang setiap hari untuk mengetahui rataan konsumsi setiap ternak. Air minum diberikan secara ad libitum.

\section{Analisis Data}

Perlakuan yang diterapkan yaitu anak domba yang tidak dipisahkan dari induknya dan diberi air susu induk (PSI) dan anak domba yang dipisahkan dari induknya dan diberi milk replacer yang telah diformulasi (PMR). Data konsumsi pakan pra sapih dianalisis secara deskriptif dan data yang lain dianalisis menggunakan uji-T (Sudjana 1997) dengan bantuan program SPSS 22.

\section{Peubah yang Diamati}

Peubah yang diamati dalam penelitian ini adalah: (1) Konsumsi pakan yang dihitung dengan mengurangi jumlah pakan yang diberikan dengan pakan sisa yang tidak dimakan, (2) Pertambahan bobot badan yang diukur dengan mengurangi bobot badan akhir dengan bobot badan awal, (3) Konversi pakan yang diperoleh dari hasil pembagian jumlah pakan yang dikonsumsi dengan pertambahan bobot badan dalam waktu tertentu, dan (4) Mortalitas dan kesehatan ternak yang diperoleh berdasarkan pengamatan yang terjadi selama penelitian.

\section{HASIL DAN PEMBAHASAN}

\section{Konsumsi Pakan Pra Sapih}

Konsumsi pakan anak pra sapih hanya dapat diperoleh dari anak domba yang dipisahkan dari induknya yang mengonsumsi milk replacer (PMR). Konsumsi pakan anak domba pra sapih disajikan pada Tabel 3 . Sumber nutrien domba yang baru lahir sampai pra sapih sebagian besar berasal dari air susu dan mulai sedikit tambahan asupan nutrien yang berasal dari mengonsumsi konsentrat dan hijauan. Hal tersebut dikarenakan rumen domba belum dapat berfungsi dengan sempurna sampai domba berumur sekitar 4 minggu (Tiesnamurti et al., 2002). 
Tabel 3. Konsumsi bahan kering pakan anak domba yang diberi Milk Replacer pra sapih umur 14 - 60 hari

\begin{tabular}{lcc}
\hline \multirow{2}{*}{ Pakan } & \multicolumn{2}{c}{ Konsumsi } \\
\cline { 2 - 3 } & (g/ekor/hari) & $(\%)$ \\
\hline Milk & $100,85 \pm$ & 61,4 \\
replacer & 19,40 & 19,4 \\
Hijauan & $31,89 \pm 7,27$ & 19,1 \\
Konsentrat & $31,44 \pm 5,70$ & 100,0 \\
\hline Total & $164,18 \pm$ & \\
& 31,25 & \\
\hline
\end{tabular}

Pada penelitian ini rataan konsumsi BK milk replacer adalah 100,85 g/ekor/hari. Nilai konsumsi milk replacer pada penelitian ini lebih rendah dibandingkan hasil yang diperoleh Chiou dan Jordan (1973) yang melakukan penelitian dengan memberikan milk replacer dengan kandungan lemak berbeda dengan rataan 180 g/ekor/hari. Hal tersebut dapat disebabkan frekuensi pemberian yang berbeda. Pada penelitian yang dilakukan Chiou dan Jordan (1973) milk replacer diberikan secara ad libitum sedangkan pada penelitian ini milk replacer hanya diberikan tiga kali dalam sehari.

Konsumsi BK pada anak domba yang diberi susu induk (PSI) tidak dapat dihitung dengan pasti. Estimasi hanya dapat dilakukan dengan melihat pertambahan bobot badan anak. Dove (1988) menyatakan bahwa untuk menghasilkan $1 \mathrm{~kg}$ pertambahan bobot badan anak, anak domba perlu mengonsumsi susu sebanyak $6 \mathrm{~kg}$. Dengan menggunakan persamaan tersebut maka konsumsi susu anak domba PSI adalah sekitar 118,45 g/ekor/hari. Jika dibandingkan dengan konsumsi milk replacer, maka tentu saja konsumsi susu induk lebih banyak. Faktor yang mempengaruhi lebih tingginya konsumsi BK pakan pada anak yang tetap dikandangkan bersama induknya antara lain yaitu anak merasa lebih nyaman dan tidak merasakan cekaman yang mengakibatkan turunnya konsumsi pakan. Faktor lain juga dapat disebabkan frekuensi pemberian yang berbeda, anak yang mengonsumsi susu induknya (PSI) dapat kapan saja menyusu, tetapi tidak demikian halnya dengan anak yang diberi milk replacer. Namun nilai tersebut belum memperhitungkan konsumsi pakan lain, yaitu hijauan dan konsentrat, yang tidak dapat dihitung karena bercampur dengan konsumsi induknya.

\section{Konsumsi Pakan Pasca Sapih}

Dikarenakan konsumsi pakan pra sapih (sebelum umur 60 hari) hanya dapat diukur pada anak domba yang dipisah dari induknya pada umur 2 minggu dan diberikan milk replacer, maka konsumsi pakan untuk dapat dibandingkan pada kedua kelompok anak domba lebih difokuskan pada umur 60 90 hari.

Tabel 4. Konsumsi pakan anak domba pasca sapih umur $60-90$ hari

\begin{tabular}{|c|c|c|}
\hline \multirow{2}{*}{ Peubah } & \multicolumn{2}{|c|}{ Perlakuan* } \\
\hline & PSI & PMR \\
\hline $\begin{array}{l}\text { Konsumsi Bahan Kering } \\
\text { (g/ekor/hari) } \\
\left(\mathrm{g} / \mathrm{kg} \mathrm{BB} B^{0.75} / \text { hari) }\right.\end{array}$ & $\begin{array}{c}201,04 \pm 19,86^{\mathrm{a}} \\
38,98 \pm 4,66\end{array}$ & $\begin{array}{c}168,61 \pm 10,20^{\mathrm{b}} \\
37,10 \pm 1,68\end{array}$ \\
\hline $\begin{array}{l}\text { Konsumsi Energi } \\
\quad(\mathrm{Kkal} / \mathrm{ekor} / \mathrm{hari}) \\
\quad\left(\mathrm{Kkal} / \mathrm{kg} \mathrm{BB} \mathrm{BB}^{0.75} / \text { hari) }\right.\end{array}$ & $\begin{array}{c}901,67 \pm 88,51^{\mathrm{a}} \\
178,43 \pm 20,79\end{array}$ & $\begin{array}{r}756,20 \pm 44,94^{\mathrm{b}} \\
166,42 \pm 7,63\end{array}$ \\
\hline $\begin{array}{l}\text { Konsumsi Protein } \\
\text { (g/ekor/hari) } \\
\quad\left(\mathrm{g} / \mathrm{kg} \mathrm{BB} \mathrm{BB}^{0.75} / \text { hari }\right)\end{array}$ & $\begin{array}{c}27,59 \pm 2,58 \\
5,35 \pm 0,61\end{array}$ & $\begin{array}{c}23,14 \pm 1,21 \\
5,10 \pm 0,26\end{array}$ \\
\hline
\end{tabular}

*) PSI: anak domba yang memperoleh susu induk; PMR: anak domba yang memperoleh milk replacer Superskrip yang berbeda pada baris yang sama menunjukkan berbeda nyata $(\mathrm{P}<0,05)$ 
Konsumsi bahan kering, protein kasar, dan energi anak domba pasca sapih disajikan pada Tabel 4. Aaron et al. (1997) melaporkan bahwa penyapihan domba anak pada umur 60 hari tidak mengganggu pertumbuhan anak selanjutnya. Setelah disapih, anak domba akan mengonsumsi pakan padat berupa konsentrat dan hijauan untuk memenuhi kebutuhan nutriennya.

Konsumsi BK dan energi pakan umur 60 - 90 hari anak domba pada perlakuan PSI (201,04 g/ekor/hari) lebih tinggi $(\mathrm{P}<0,05)$ daripada anak domba pada perlakuan PMR (168,61g/ekor/hari). Perbedaan tersebut nampaknya terutama disebabkan adanya perbedaan bobot sapih anak domba (Tabel 5). Anak domba pada kelompok PSI memiliki bobot sapih yang lebih tinggi daripada PMR, sehingga anak domba PSI memperoleh pakan yang lebih banyak, akibatnya dapat mengonsumsi $\mathrm{BK}$ dan energi yang lebih banyak. Hal tersebut sesuai dengan pendapat yang dikemukakan oleh McDonald (2011) dan Forbes (2007) bahwa konsumsi BK sangat dipengaruhi oleh bobot hidup. Kecilnya bobot sapih anak domba kelompok PMR disebabkan mereka mengalami cekaman karena dipisahkan dari induknya lebih awal pada umur 14 hari.

Konsumsi BK dan energi yang dihitung berdasarkan bobot badan metabolis menunjukkan hasil yang tidak berbeda nyata $(\mathrm{P}>0,05)$ untuk kedua perlakuan (Tabel 4), yaitu berturut-turut konsumsi BK $37,10 \mathrm{~g} / \mathrm{kg}$ $\mathrm{BB}^{0.75}$ untuk PMR dan $38,98 \mathrm{~g} / \mathrm{kg} \mathrm{BB} \mathrm{BB}^{0.75}$ untuk PSI dan konsumsi energi 178,43 $\mathrm{Kkal} / \mathrm{kg} \mathrm{BB} \mathrm{B}^{0.75} /$ hari untuk PMR dan 166,42 $\mathrm{Kkal} / \mathrm{kg} \mathrm{BB}{ }^{0.75} /$ hari untuk PSI. Hal ini dapat diartikan bahwa sebenarnya kemampuan mengonsumsi pakan pada kedua kelompok anak domba tersebut adalah sama.

Konsumsi protein anak domba umur 60 - 90 hari memiliki pola yang sama dengan konsumsi BK dan energi, lebih tinggi pada anak domba PSI daripada PMR, namun secara statistik tidak berbedanyata $(\mathrm{P}>0,05)$ (Tabel 4). Pada penelitian ini konsumsi protein berkorelasi positif dengan konsumsi energi. Semakin tinggi konsumsi protein maka konsumsi energi juga akan semakin tinggi, hal tersebut dikarenakan pemanfaatan protein untuk dapat diubah menjadi protein tubuh memerlukan ketersediaan energi yang cukup (Chowdhury dan Orskov, 1997). Ada data yang menarik, ternyata kedua kelompok anak domba mengonsumsi energi (Kkal/ekor/hari) dan protein (g/ekor/hari) dengan rasio yang sama, yaitu 32,68.

\section{Pertambahan Bobot Badan Pra Sapih dan Bobot Badan Saat Sapih}

Pertambahan bobot badan anak domba pra sapih (umur 14 hari sampai dengan 60 hari) dan bobot badan saat sapih disajikan pada Tabel 5. Pertambahan bobot badan dan bobot badan saat sapih anak domba yang mendapatkan asupan susu yang berasal dari induknya (PSI) lebih tinggi $(\mathrm{P}<0,05)$ berturut-turut yaitu 115,7 g/ekor/hari dan 8,3 kg/ekor dibandingkan dengan anak domba yang diberikan milk replacer (PMR) yaitu 61,5 g/ekor/hari dan $6,8 \mathrm{~kg} / \mathrm{ekor}$. Pertumbuhan berkorelasi positif dengan jumlah konsumsi dan kualitas pakan (dos Santos, 2017).

Penyebab dari rendahnya PBB anak yang diberikan milk replacer yang pertama mungkin karena lebih rendahnya kualitas dari milk replacer jika dibandingkan dengan susu induk. Hal tersebut dapat dilihat pada kandungan protein dan lemak milk replacer yang lebih rendah dibandingkan susu induk (Tabel 1). Penyebab kedua yang mungkin mempengaruhi adalah cekaman yang dialami anak domba karena dipisahkan lebih awal dengan induknya. Kondisi cekaman dapat menurunkan nafsu makan sehingga konsumsi pakan dapat menurun. Penyebab ketiga adalah anak yang dikandangkan bersama induknya dapat belajar mengikuti pola makan induknya, sehingga dapat lebih cepat dan banyak dalam mengonsumsi konsentrat dan hijauan dibandingkan anak yang dipisahkan dengan induknya. Hal tersebut sejalan dengan pendapat Hidayati et al. (2002) yang menyatakan bahwa ternak yang dikandangkan pada kandang individu akan mengalami cekaman yang lebih tinggi dibandingkan ternak yang dikandangkan pada kandang kelompok sehingga akan 
mempengaruhi konsumsi pakan dan pertambahan bobot badannya. Anak yang diberi milk replacer dikandangkan secara individu, terpisah dari induknya dan anak domba lain sejak umur dua minggu, sedangkan anak yang mengonsumsi susu induknya dikandangkan bersama dengan induknya sehingga tidak mengalami cekaman pada umur awal.

Tabel 5. Bobot badan, pertambahan bobot badan harian dan konversi pakan anak domba selama penelitian

\begin{tabular}{|c|c|c|}
\hline \multirow{2}{*}{ Peubah } & \multicolumn{2}{|c|}{ Perlakuan* } \\
\hline & PSI & PMR \\
\hline BB hari ke-14 (kg/ekor) & $3,6 \pm 0,2$ & $4,1 \pm 0,6$ \\
\hline BB hari ke-60 (kg/ekor) & $8,3 \pm 0,7^{\mathrm{a}}$ & $6,8 \pm 0,5^{b}$ \\
\hline BB hari ke-90 (kg/ekor) & $9,9 \pm 1,6$ & $8,7 \pm 1,1$ \\
\hline PBB hari ke 14-60 (g/ekor/hari) & $115,7 \pm 17,7^{\mathrm{a}}$ & $61,5 \pm 13,0^{b}$ \\
\hline PBB hari ke 60-90 (g/ekor/hari) & $57,1 \pm 31,1^{\mathrm{b}}$ & $67,3 \pm 29,9^{a}$ \\
\hline Konversi pakan $60-90$ hari & $4,2 \pm 1,8$ & $2,8 \pm 1,1$ \\
\hline
\end{tabular}

\section{Bobot Sapih}

Menurut Tiesnamurti et al. (2002) penyapihan dapat dilakukan setelah anak domba tidak terlalu menggantungkan konsumsinya hanya pada susu induk dan telah dapat mengonsumsi pakan padat dengan cukup baik. Pada penelitian ini, anak domba umur 60 hari telah dapat disapih, hal tersebut terlihat dari frekuensi menyusu pada anak domba yang dikandangkan bersama induknya sudah semakin berkurang. Berdasarkan hasil penelitian Maryadi et al. (1985) penyapihan anak domba pada umur 60 hari lebih baik daripada penyapihan pada umur 90 hari.

Hasil analisis statistik menunjukkan perlakuan memberikan pengaruh yang nyata $(\mathrm{P}<0,05)$ terhadap bobot sapih anak domba (BB umur 60 hari) (Tabel 5). Bobot sapih anak domba kelompok PSI lebih tinggi $(8,3$ kg) daripada anak domba kelompok PMR $(6,8 \mathrm{~kg})$. Pertambahan bobot badan umur 14 - 60 hari nampaknya menjadi faktor yang paling berpengaruh terhadap bobot sapih, dimana PBB pada anak yang diberikan milk replacer lebih rendah $(\mathrm{P}<0,05)$ dibandingkan pertambahan bobot badan anak domba yang mengonsumsi susu induk. Bobot sapih juga sangat dipengaruhi oleh bobot lahir (awal), kemampuan induk menyediakan susu, dan agresivitas anak menyusu (Tiesnamurti et al., 2002). Dalam penelitian ini meskipun pada umur 14 hari bobot awal anak domba pada kelompok PMR lebih tinggi dari bobot anak domba pada kelompok PSI, namun setelah itu anak domba PMR mengalami cekaman karena dipisahkan dari induknya yang mengakibatkan pertumbuhannya terganggu (PBB umur 14 - 60 hari: 61,5 g/ekor/hari, Tabel 5). Di lain pihak, anak yang menyusu pada induknya merasa lebih nyaman dan tidak mengalami cekaman sebelum penyapihan (PBB umur 14 - 60 hari: 115,7 g/ekor/hari, Tabel 5).

\section{Pertambahan Bobot Badan Pasca Sapih dan Bobot Badan Umur 90 hari}

Penelitian ini memperlihatkan bahwa PBBH umur $14-60$ hari lebih tinggi daripada PBBH umur $60-90$ hari. Pertambahan bobot badan harian pada anak domba setelah disapih menunjukkan perbedaan yang nyata $(\mathrm{P}<0,05)$ antara kedua perlakuan (Tabel 5). Pertambahan bobot badan harian anak domba lepas sapih (umur 60 - 90 hari) yang diberikan milk replacer $(\mathrm{PMR})$ lebih tinggi $(\mathrm{P}<0,05)$ dibandingkan dengan anak domba lepas sapih yang menyusui dengan induknya (PSI). Fakta ini diluar perkiraan karena bobot sapih anak domba kelompok PMR lebih rendah daripada kelompok PMI. Pada umumnya sebagaimana hasil penelitian yang dilaporkan oleh Fraser dan Saville (2000) bahwa bobot 
sapih berkorelasi positif terhadap laju pertumbuhan dan bobot hidup ternak. Perbedaan tersebut diperkirakan karena tingkat cekaman domba yang baru dipisahkan dari induknya pada umur 60 hari (PSI) lebih tinggi daripada domba yang dipisah dari induknya umur 14 hari dan selanjutnya diberi milk replacer sampai umur 60 hari (PMR). Hal tersebut ditandai dengan penurunan bobot badan pada anak domba PMR pada minggu pertama setelah disapih, sedangkan pada anak domba yang diberi milk replacer, meskipun adanya perubahan pemberian jenis pakan ke konsentrat dan hijauan seluruhnya, namun tidak terjadi penurunan bobot badan. Hal ini menunjukkan cekaman karena dipisah dari induknya lebih besar pengaruhnya terhadap PBB daripada cekaman beradaptasi dengan jenis pakan baru.

Secara keseluruhan PBBH anak domba dalam penelitian ini dari umur 14 90 hari adalah sebesar 82,89 g (PSI) dan 60,53 g (PMR). Peneliti lain (Inounu et al.,1993) melaporkan bahwa domba ekor tipis pertambahan bobot badan harian anak domba kembar dua yang dipelihara selama 0 - 3 bulan adalah 96,00 g, sedangkan pada domba Garut (Inounu et al.,2003) adalah 98,61 g. Perbedaan PBBH ini selain karena beda secara genetik, juga karena pada penelitian Inounu et al. (1993) dan Inounu et al. (2003) anak domba disapih pada umur 90 hari. Penelitian O'Ferrall dan Timon (1977) menggunakan delapan bangsa domba berbeda juga menunjukkan adanya perbedaan dalam bobot lahir, bobot sapih dan pertambahan bobot badan harian. Namun menurut penelitian yang dilakukan oleh Suryadi (2006), pertambahan bobot badan harian domba kembar sebesar 66,40 g. Nilai ini hampir sama dengan PBBH pada anak domba yang diberikan milk replacer, oleh sebab itu meskipun pertambahan bobot badan harian anak domba yang diberi milk replacer rendah, nilai tersebut masih dapat dikategorikan normal.

Akibat PBB yang rendah pada umur 60 - 90 hari pada anak domba PSI, bobot badan anak domba PSI pada hari ke-90 menjadi tidak berbeda nyata $(\mathrm{P}>0,05)$ dengan bobot badan anak domba PMR (Tabel 5). Bobot badan pada hari ke-90 pada penelitian ini berkisar antara 8,68 - 9,87 kg. Nilai tersebut lebih tinggi dibandingkan bobot badan pasca sapih yang diperoleh pada penelitian Subandriyo et al. (2000) yang melakukan penyapihan pada hari ke-90 dan mendapatkan bobot badan pasca sapih pada umur 112 hari sebesar 9,04 kg pada anak domba dengan kelahiran kembar. Ini membuktikan bahwa penyapihan pada umur 60 hari tidak memberikan efek yang buruk sama sekali pada pertumbuhan domba. Selain itu, pemisahan yang dilakukan pada domba kembar terbukti dapat meningkatkan bobot badan baik pada domba yang tetap dikandangkan bersama induknya maupun domba yang diberi milk replacer.

\section{Konversi Pakan}

Hasil analisis statistik menunjukkan kedua kelompok perlakuan tidak berbeda nyata $(\mathrm{P}>0,05)$ dalam nilai konversi pakan dari umur 60 - 90 hari. Meskipun demikian, nilai konversi pakan anak domba yang diberi milk replacer lebih baik dari anak domba yang mengonsumsi susu induk. Hal tersebut menggambarkan bahwa domba yang mengonsumsi milk replacer (PMR) dapat mengonsumsi dan memanfaatkan pakan padat lebih efisien dibandingkan anak yang dikandangkan bersama induknya (PSI). Hal yang menyebabkan tingginya konversi pakan pada PSI mungkin karena terjadinya cekaman saat disapih sehingga terjadi penurunan bobot badan pada anak domba PSI.

Nilai konversi pakan pasca sapih pada penelitian ini adalah 2,83 (PMR) dan 4,15 (PSI). Nilai konversi pakan pada penelitian ini lebih baik dibandingkan nilai konversi pakan yang diperoleh pada penelitian Yulistiani et al. (2000) yang melakukan penelitian pada domba komposit betina lepas sapih yang diberi suplementasi glirisidia dengan nilai konversi pakan sebesar 7,23. Hal tersebut tentu dikarenakan pakan yang diberikan pasca sapih pada penelitian ini memiliki kualitas yang baik sehingga dapat 
dimanfaatkan secara efisien oleh tubuh ternak. Sejalan dengan hasil tersebut adalah penelitian yang dilaporkan oleh Ma et al. (2019) bahwa efisiensi pemanfaatan pakan sangat dipengaruhi oleh kualitas pakan yang dikonsumsi.

\section{Mortalitas dan Kesehatan Ternak}

Pada penelitian ini tidak ada kematian pada seluruh anak domba baik yang mengonsumsi susu induk maupun yang mengonsumsi milk replacer. Pada umumnya kematian anak domba kembar dua umur 0 - 3 hari sebesar 30\% dan pada umur 90 hari sebesar 40\% (Adiati dan Subandriyo, 2007).

Milk replacer yang diberikan terbukti tidak memberikan efek buruk pada anak domba. Anak domba juga tidak mengalami gangguan pencernaan seperti diare yang disebabkan milk replacer. Selain itu tidak terdapat adanya gejala kurang nafsu makan dan lemas selama penelitian berlangsung. Anak domba juga tetap dapat berinteraksi dengan cukup baik. Bahkan, domba yang diberi milk replacer terbukti lebih interaktif karena telah lebih berpengalaman terpisah dari induknya.

\section{KESIMPULAN}

Penyapihan dini dengan pemberian milk replacer terbukti dapat menghasilkan anak domba yang sehat dengan tidak ada kematian, meskipun pada umur 60 hari bobot badannya lebih rendah daripada anak domba yang mengonsumsi susu induk. Namun laju pertumbuhan pasca sapih dan konversi pakan anak yang diberikan milk replacer lebih baik daripada anak domba yang mengonsumsi susu induk, sehingga bobot badan pada umur 90 hari tidak berbeda antara kedua kelompok anak domba.

\section{DAFTAR PUSTAKA}

Aaron, D. K., D. G. Ely, W. P. Deweese, E. Fink and C. R. Gatke. 1997. Reducing milk production in ewes atweaning using restricted feeding and methscopolamine bromide. J. Anim. Sci. 75:1434-1442.
Adiati, U. dan Subandriyo. 2007. Produktivitas domba Garut pada stasiun percobaan Cilebut Bogor. Seminar Nasional Peternakan dan Veteriner. Pusat Penelitian dan Pengembangan Peternakan. Bogor. Pp:436-440.

Chiou, P. W. S., and R. M. Jordan. 1973. Ewe milk replacer for young lanbs. I. Effect of age of lamb and dietary fat on digestibility of the diet, nitrogen retention and plasma constituents. J. Anim. Sci. 36:597-603.

Chowdhury, S. A. dan E. R. Orskov. 1997. Protein energy relationships with particular references to energy undernutrition : Areview. Small Ruminant Research. 26:1-7.

dos Santos, V. R.V., C. McManus, V. Peripolli, C. B. Tanure, P. M.T. Lima, P. S. Corrêa, D. L. Brito, S. E. F de Araújo dan H. Louvandini. 2017. Dry matter intake, performance and carcass characteristics of hair sheep reared under different grazing systems. Scientia Agricola. 74: 436442. https://dx.doi.org/10.1590/1678992x-2016-0290

Dove, H. 1988. Estimating the intake of milk by lambs, from the turn over of deuterium- or tritium-labelled water. J. British of Nutrition. 60: 375-387.

Forbes, J. M. 2007.Voluntary Food Intake and Diet Selection in Farm Animals. $2^{\text {nd }}$ Ed. CAB International, Wallingford, UK.

Fraser, T. J. dan D. J. Saville. 2000. The effect of weaning weight on subsequent lamb growth rates.Proceedings of the New Zealand Grassland Association. 62: 75-79.

Hidayati, N., M. Martawidjaja dan I. Inounu. 2002. Peningkatan energi ransum untuk pertumbuhan domba persilangan. Seminar Nasiona 
Peternakan dan Veteriner. Pusat Penelitian dan Pengembangan Peternakan. Bogor. Pp: 202-205.

Inounu, I., L. C. Iniguez, G. E. Bradford, Subandriyo dan B. Tiesnamurti. 1993. Performance production of prolific Javanese ewes. Small Ruminant Research. 12: 243-257.

Inounu, I., N. Hidayati, Subandriyo, B. Tiesnamurti dan L. O. Nafiu. 2003. Analisis keunggulan relatif domba Garut anak dan persilangannya. JITV. 8: 164-169.

Ma,T., F. Wan, D. Yang, K. Deng, K. Yang dan Q. Diao. 2019. Growth performance, nutrient digestibility, and slaughter traits ofmale fattening lambs under different feeding standards. Animal Nutrition. 5: 74-79.

Maryadi, B., Hartoko, A. Adnan dan S. Adjisoedarmo, 1985. Pertumbuhan anak domba lepas sapih dengan umur penyapihan yang berbeda. Media Vet. 5:12-16.

McDonald, P., R. A. Edwards, J. F. D. Greenhalgh, C. A. Morgan, L. A. Sinclair, R. G. Wilkinson. 2011. Animal Nutrition. $7^{\text {th }}$ Ed. Prentice Hall, London, UK.

O'Ferrall, G.J.M. danV. M. Timon. 1977. A Comparison of Eight Sire Breeds for Lamb Production: 1. Lamb Growth and Carcass Measurements. Ir J Agric Res. 16: 267-275.

Subandriyo, B. Setiadi, E. Handiwirawan dan A. Suprayanto. 2000. Performa domba komposit hasil persilangan antara domba lokal Sumatera dan domba rambut pada kondisi dikandangkan. JITV. 5 (2):73-83.

Sudjana, M.A. 1997. Metode Statistik.Edisi ke-5. Tarsito. Bandung.

Sugiyono. 2011. Domba komposit, tingkatkan mutu genetika domba lokal.http://www.Livestockreview.Ris et.com [1 Maret 2012].

Suryadi, U. 2006. Pengaruh jumlah anak sekelahiran dan jenis kelamin terhadap kinerja anak domba sampai sapih. Politeknik Negri Jember. Jember.

Tiesnamurti, B. 1992. Reducing the preweaning mortality rate of Javanese thin-tail sheep. In: New technologiesfor small ruminant production in Indonesia. P. J. Ludgate (Ed.). Winrock International Institute for Agriculture Development. Pp: 93101.

Tiesnamurti, B., I. Inounu dan Subandriyo. 2002. Kapasitas produksi susu domba peridi : I. Pertumbuhan anak prasapih. JITV. 7 : 227-236.

Yulistiani, D., B. Tiesnamurti, Subandriyo, M. Rangkuti dan L. Praharani. 2000. Produktivitas domba komposit betina lepas sapih yang diberi suplementasi glisiridia. Seminar Nasional Peternakan dan Veteriner. Pusat Penelitian dan Pengembangan Peternakan. Bogor. Pp: 263-269. 